University of Nebraska - Lincoln

DigitalCommons@University of Nebraska - Lincoln

Faculty Publications from the Harold W. Manter Laboratory of Parasitology

8-1992

\title{
Congruent and Synchronic Patterns in Biogeography and Speciation among Seabirds, Pinnipeds, and Cestodes
}

\author{
Eric P. Hoberg \\ United States Department of Agriculture, ehoberg@ggpl.arsusda.gov
}

Follow this and additional works at: https://digitalcommons.unl.edu/parasitologyfacpubs

Part of the Parasitology Commons

Hoberg, Eric P., "Congruent and Synchronic Patterns in Biogeography and Speciation among Seabirds, Pinnipeds, and Cestodes" (1992). Faculty Publications from the Harold W. Manter Laboratory of Parasitology. 401.

https://digitalcommons.unl.edu/parasitologyfacpubs/401

This Article is brought to you for free and open access by the Parasitology, Harold W. Manter Laboratory of at DigitalCommons@University of Nebraska - Lincoln. It has been accepted for inclusion in Faculty Publications from the Harold W. Manter Laboratory of Parasitology by an authorized administrator of DigitalCommons@University of Nebraska - Lincoln. 


\title{
CONGRUENT AND SYNCHRONIC PATTERNS IN BIOGEOGRAPHY AND SPECIATION AMONG SEABIRDS, PINNIPEDS, AND CESTODES*
}

\author{
Eric P. Hoberg \\ United States Department of Agriculture, Agricultural Research Service, Biosystematic Parasitology Laboratory, \\ BARC-East, Building 1180, 10300 Baltimore Avenue, Beltsville, Maryland 20705-2350
}

\begin{abstract}
Congruence in biogeographic patterns among diverse assemblages of taxa indicates uniformity in the historical determinants of biotic distributions. Comparisons of host and parasite phylogenies and the elucidation of distributional area relationships are requisite components of analyses in historical biogeography. Host-parasite associations with broad geographic ranges are often archaic and have been structured largely by coevolutionary processes. In contrast, the origins and radiation of the primary cestode faunas of some seabirds (Alcataenia spp./Alcidae) and pinnipeds (Anophryocephalus spp./Phocidae and Otariidae) are associated with colonization. These young colonizing faunas, in the Holarctic Region, were influenced by a common history during the late Pliocene and Pleistocene epochs. Periodic range contraction, with isolation in refugial centers, and subsequent expansion into postglacial habitats for hosts and parasites coincided with the cyclic pattern of stadials and interstadials. During the past 2-3 million years following colonization, these dramatic climatic fluctuations strongly influenced the continuity of ecological associations in marine habitats and appear to have been the determinants of congruent and synchronic patterns of speciation among these disparate taxa of marine homeotherms and eucestodes.
\end{abstract}

Historical biogeography constitutes the study of pattern and process in the distribution of organisms. Biogeographers develop phylogenetic hypotheses and search for congruence in broad generalized patterns among disparate monophyletic taxa. Congruence in biogeographic patterns among groups of unrelated taxa is indicative of simultaneous cause as a primary determinant of biotic distribution.

Patterns of host association and historical biogeography may be examined within the framework of phylogenetic systematics (Hennig, 1966; Wiley, 1981; Brooks and McLennan, 1991). A hypothesis for coevolution is corroborated by consistency and congruence of host-parasite phylogenies. Predictions would include a protracted association for hosts and parasites, a high degree of cospeciation and coadaptation, and possible recognition of numerical and phylogenetic relicts (Brooks and Bandoni, 1988; Brooks and McLennan, 1991). In contrast, inconsistent and incongruent phylogenies are expected in assemblages structured by colonization. Predictions would include a similarity in host trophic ecology, geographically delimited faunas, and associations of variable temporal extent and degree

Received 29 October 1991; revised 17 January 1992; accepted 30 January 1992.

* Paper from the von Ihering Centenary Symposium on parasite biogeography and coevolution presented at the 1991 annual meeting of the American Society of Parasitologists. of cospeciation/coadaptation as determined by the time frame for colonization of the host clade (Hoberg, 1986; Brooks and McLennan, 1991). Within this context the temporal duration of an assemblage may be evaluated with respect to host-parasite distribution, historical biogeography of the hosts, and aspects of regional history and physical geography (Hoberg, 1986; Hoberg and Adams, 1992). These factors represent requisite components in analyses of host-parasite biogeography and evolution.

Previous analyses of host-parasite relationships have involved widespread and archaic assemblages that have been structured by coevolution and vicariant, often tectonic, processes (see Brooks and McLennan [1991] and references therein). In contrast, in the Holarctic Region relatively young associations of hosts and parasites have originated and diversified since the late Pliocene epoch (over the past 3 million years). Hypotheses developed for dilepidid and tetrabothriid cestodes among seabirds (Hoberg, 1986, 1991) and pinnipeds (Hoberg and Adams, 1992), respectively, suggest that these faunas originated via host-switching and were structured largely by sequential colonization and extreme climatic variation during the Pleistocene epoch. It was during the late Pliocene epoch and Quaternary period that large-scale (e.g., North Pacific basin, Arctic basin, Okhotsk Sea) and insular (e.g., Aleutian Islands, Kurile Islands) marine refugia developed during glacial maxima. Refugia were 
TABle I. Character matrix for species of Alcataenia, modified from Hoberg (1986).

\begin{tabular}{|c|c|c|c|c|c|c|c|c|c|c|c|c|c|c|c|}
\hline \multirow[b]{2}{*}{ Species } & \multicolumn{15}{|c|}{ Character* } \\
\hline & 1 & 2 & 3 & 4 & 5 & 6 & 7 & 8 & 9 & 10 & 11 & 12 & 13 & 14 & 15 \\
\hline A. larina $\dagger$ & 1 & 1 & $0 \ddagger$ & 0 & 0 & 0 & 0 & 0 & 0 & 0 & 0 & 0 & 0 & 0 & 0 \\
\hline A. campylacantha & 1 & 1 & 0 & 1 & 2 & 0 & 1 & 0 & 1 & 1 & 0 & 0 & 1 & 0 & 0 \\
\hline A. armillaris & 1 & 1 & 1 & 1 & 1 & 1 & 0 & 0 & 1 & 1 & 1 & 1 & 0 & 0 & 0 \\
\hline A. meinertzhageni & 1 & 1 & 0 & 1 & 2 & 1 & 1 & 0 & 2 & 1 & 0 & 0 & 1 & 1 & 1 \\
\hline A. longicervica & 1 & 1 & 1 & 1 & 1 & 1 & 0 & 0 & 1 & 1 & 2 & 0 & 1 & 1 & 1 \\
\hline A. pygmaeus & 2 & 1 & 1 & 1 & 1 & 1 & 1 & 1 & 0 & 0 & 0 & 0 & 0 & 0 & 0 \\
\hline A. fraterculae & 1 & 1 & 1 & 0 & 0 & 0 & 0 & 0 & 0 & 0 & 0 & 0 & 0 & 0 & 0 \\
\hline A. cerorhincae & 1 & 1 & 1 & 1 & 0 & 0 & 0 & 0 & 0 & 0 & 0 & 0 & 0 & 0 & 0 \\
\hline A: atlantiensis & 1 & 1 & 1 & 1 & 0 & 0 & 0 & 0 & 0 & 0 & 0 & 0 & 0 & 0 & 1 \\
\hline
\end{tabular}

* Definition of characters as follows: 1 , genital atrium; 2 , uterus; 3 , genital ducts; 4 , wall of vagina; 5 , size of hooks; 6 , position in host; 7 , wall of cirrus sac; 8 , sphincter on seminal receptacle; 9 , position of hooks; 10 , ovary; 11 , length of neck; 12 , shape of proglottid; 13 , length of cirrus sac; 14, number of testes; 15 , position of female organs. Character coding is as follows: 0, plesiomorphic; 1 and 2, apomorphic (see Hoberg, 1986).

$\dagger$ Alcataenia larina larina and Alcataenia larina pacifica combined; tree rooted with Alcataenia larina (see Hoberg, 1986).

$\ddagger$ Character with primitive and derived states coded as plesiomorphic.

significant in promoting isolation and subsequent speciation among hosts and parasites, particularly in the Beringian region that alternately functioned as a corridor or barrier for marine dispersal, coinciding with eustatic fluctuations in sea level (following initial opening of the Bering Strait 3.0-3.5 million years ago [mya]) (Herman and Hopkins, 1980; Matthews, 1981).

The biotic and physical realm of the North Pacific basin, Arctic Ocean, and North Atlantic basin influenced the diversification of species of the genus Alcataenia Spasskaya, 1971 (Eucestoda: Dilepididae) among the seabird family Alcidae (Charadriiformes; but see Chandler [1990a] for an alternate hypothesis for higher level relationships of Alcidae) and species of the genus Anophryocephalus Baylis, 1922 (Eucestoda: Tetrabothriidae) among the Phocidae and Otariidae ("Pinnipedia"). Narrow host and geographic distributions for these assemblages are distinctive, suggesting a common history with generalized climatological influences as determinants of isolation and speciation. Congruence in temporal and biogeographic patterns and a broadly synchronic history for diversification are postulated for these phylogenetically disparate host and parasite taxa. An integrated hypothesis for the evolutionary history and biogeography of these faunas is summarized. Additionally, evidence presented in the current study (see also Hoberg, 1986; Hoberg and Adams, 1992) is consistent with a novel Arctic refugium hypothesis, presented here for the first time, that recognizes high boreal latitudes as important centers of organismal diversification as opposed to centers of extinction in marine communities during the Quaternary period.

\section{MATERIALS AND METHODS}

Details of morphological studies and phylogenetic analysis of Anophryocephalus species have been documented previously (Hoberg et al., 1991; Hoberg and Adams, 1992). Characters mapped onto the phylogenetic tree presented herein for Anophryocephalus species are consistent with those morphological attributes analyzed by Hoberg and Adams (1992).

Subsequent to the original cladistic analysis of $\mathrm{Al}$ cataenia species (Hoberg, 1986), Alcataenia atlantiensis Hoberg, 1991, was described (Hoberg, 1991). Consequently, a new phylogenetic analysis is presented for the genus. Eight species from alcids were included; 15 characters were analyzed with the ALLTREES option of PAUP 2.4 (Swofford, 1985), and trees were rooted with the basal member of the clade, Alcataenia larina (Krabbe, 1869) (with the subspecies Alcataenia larina larina (Krabbe, 1869) and Alcataenia larina pacifica Hoberg, 1984, combined).

Characters and polarization of transformation series are consistent with the original analysis, except characters 3 and 4 . These latter characters originally were coded to represent postulated instances of independent derivation of states for the position of the genital ducts in the 2 subspecies of $A$. larina (between or variable in position, relative to the osmoregulatory canals) and other Alcataenia species (between or dorsal). As the present analysis does not extend to the subspecific level, characters 3 and 4 (from Hoberg, 1986) have been combined as a single character (3) for the position of the genital ducts. To do otherwise would mean that character 3 (of Hoberg, 1986) would be invariable within the ingroup and thus would not be phylogenetically informative. This change does not constitute a new interpretation for coding of this morphological attribute.

Fifteen characters were included in the analysis of Alcataenia species. Details for character state polarization were presented by Hoberg (1986) and are in the revised data matrix presented herein (Table I). The following morphological characters were included: structure of the genital atrium, ontogeny and structure of the uterus, position of the genital ducts (characters 3 and 4 of Hoberg [1986] combined with 2 states, 
TABLE II. Host and geographic distribution for species of Anophryocephalus (based on Hoberg and Adams [1992]).

\begin{tabular}{|c|c|c|}
\hline Species & Host* & Geographic range $\dagger$ \\
\hline \multirow{6}{*}{$\begin{array}{l}\text { Anophryocephalus anophrys } \\
\text { Baylis, } 1922\end{array}$} & Ringed seal & At \\
\hline & Phoca (Pusa) hispida & \\
\hline & $\begin{array}{l}\text { Harp seal, Phoca } \\
\quad(\text { Pagophilus) groenlandica } \ddagger\end{array}$ & At $\S$ \\
\hline & Harbor seal & At $\S$ \\
\hline & Phoca vitulina $\ddagger$ & \\
\hline & $\begin{array}{l}\text { Hooded seal } \\
\text { Cystophora cristata } \ddagger\end{array}$ & At \\
\hline \multirow{6}{*}{$\begin{array}{l}\text { Anophryocephalus skrjabini } \\
\quad \text { (Krotov and Deliamure, 1955) }\end{array}$} & Ringed seal & $\mathrm{P}, \mathrm{Ar}$ \\
\hline & Phoca (Pusa) hispida & \\
\hline & Ribbon seal & $\mathbf{P}$ \\
\hline & Phoca (Histriophoca) fasciata & \\
\hline & $\begin{array}{l}\text { Spotted seal } \\
\quad \text { Phoca largha }\end{array}$ & $\mathbf{P}$ \\
\hline & $\begin{array}{l}\text { Harbor seal } \\
\quad \text { Phoca vitulina richardsi }\end{array}$ & $\mathbf{P}$ \\
\hline Anophryocephalus nunivakensis & Spotted seal & $\mathbf{P}$ \\
\hline Hoberg, Adams and Rausch, 1991 & Phoca largha & \\
\hline Anophryocephalus eumetopii & Steller's sea lion & $\mathbf{P}$ \\
\hline Hoberg, Adams and Rausch, 1991 & Eumetopias jubatus & \\
\hline Anophryocephalus ochotensis & Steller's sea lion & $\mathbf{P}$ \\
\hline \multirow[t]{2}{*}{ Deliamure and Krotov, 1955} & Eumetopias jubatus & \\
\hline & $\begin{array}{l}\text { Northern fur seal } \\
\quad \text { Callorhinus ursinus }\end{array}$ & $\mathrm{P} \|$ \\
\hline
\end{tabular}

* Number of named phocid species worldwide $=19$; number of host species for Anophryocephalus $=6$ (including 3 facultative hosts); $\%=32$.

Number of named otariid species = 14; number of host species for Anophryocephalus = 2 (including 1 facultative host); $\%=14$.

† At, Arctic to subarctic of the Atlantic basin; P, Pacific basin endemic (boreal to high Arctic); Ar, western Alaskan Arctic.

$\ddagger$ Facultative ecological hosts (Hoberg et al., 1991; Hoberg and Adams, 1992).

$\S$ Single host records from the Northwestern Atlantic basin (see Hoberg and Adams, 1992)

$\|$ Host record only from Komandorskii Islands (see Iurakhno, 1987; Hoberg and Adams, 1992).

between or variable $=0$ and dorsal $=1$, being recognized), wall of vagina, size of hooks, position in host, wall of cirrus sac, sphincter associated with the seminal receptacle, position of hooks, form of ovary, length of neck, shape of proglottid, length of cirrus sac, number of testes, and position of female organs.

Phylogenetic analyses of Anophryocephalus and $\mathrm{Al}$ cataenia constituted the basis for elucidation of hostparasite associations and historical biogeography. Phylogenetic trees for host groups were derived from the literature and included analyses of Alcidae (Strauch, 1985; but see Chandler, 1990a) and the pinnipeds (Wyss, 1987, 1988a, 1989; Berta et al., 1989). Determination of consistency and congruence of phylogenetic hypotheses for hosts and parasites was based on comparisons with these respective trees. Biogeographic relationships were examined by mapping distributional data onto the parasite trees and the development of area cladograms (Brooks and McLennan, 1991).

\section{RESULTS AND DISCUSSION}

\section{Anophryocephalus spp. and Pinnipedia}

Anophryocephalus is the basal member of an inclusive group of tetrabothriids, referred to the Anophryocephalus clade (Hoberg, 1989), that has a restricted distribution among marine mammals. Species of Anophryocephalus are restricted to phocids (Anophryocephalus anophrys Baylis,
1922; Anophryocephalus skrjabini (Krotov and Deliamure, 1955); Anophryocephalus nunivakensis Hoberg, Adams and Rausch, 1991) and otariids (Anophryocephalus ochotensis Deliamure and Krotov, 1955; Anophryocephalus eumetopii Hoberg, Adams and Rausch, 1991) at high latitudes in the Holarctic Region (Table II) (Hoberg et al., 1991; Hoberg and Adams, 1992).

Striking patterns of host association (absent in Odobenidae, and the majority of Otariidae, and Phocidae) and geographic range (absent from the southern hemisphere and restricted to high latitudes of the North Pacific basin, North Atlantic and Arctic oceans) are apparent for species of Anophryocephalus. This is a depauperate fauna in pinnipeds with Anophryocephalus occurring in only $32 \%$ of phocid species (including 3 facultative ecological hosts) and $14 \%$ of otariid species (with 1 facultative host) (Table II). It is postulated that these patterns are consistent with late colonization of the host clade, subsequent to divergence of Otariidae (including cladogenesis of Otariinae and Arctocephalinae), Odobenidae, and Phocidae (Wyss, 1987, 1988a; Berta and Deméré, 1986), and that Anophryocephalus species do not constitute coevolved numerical relicts (see 

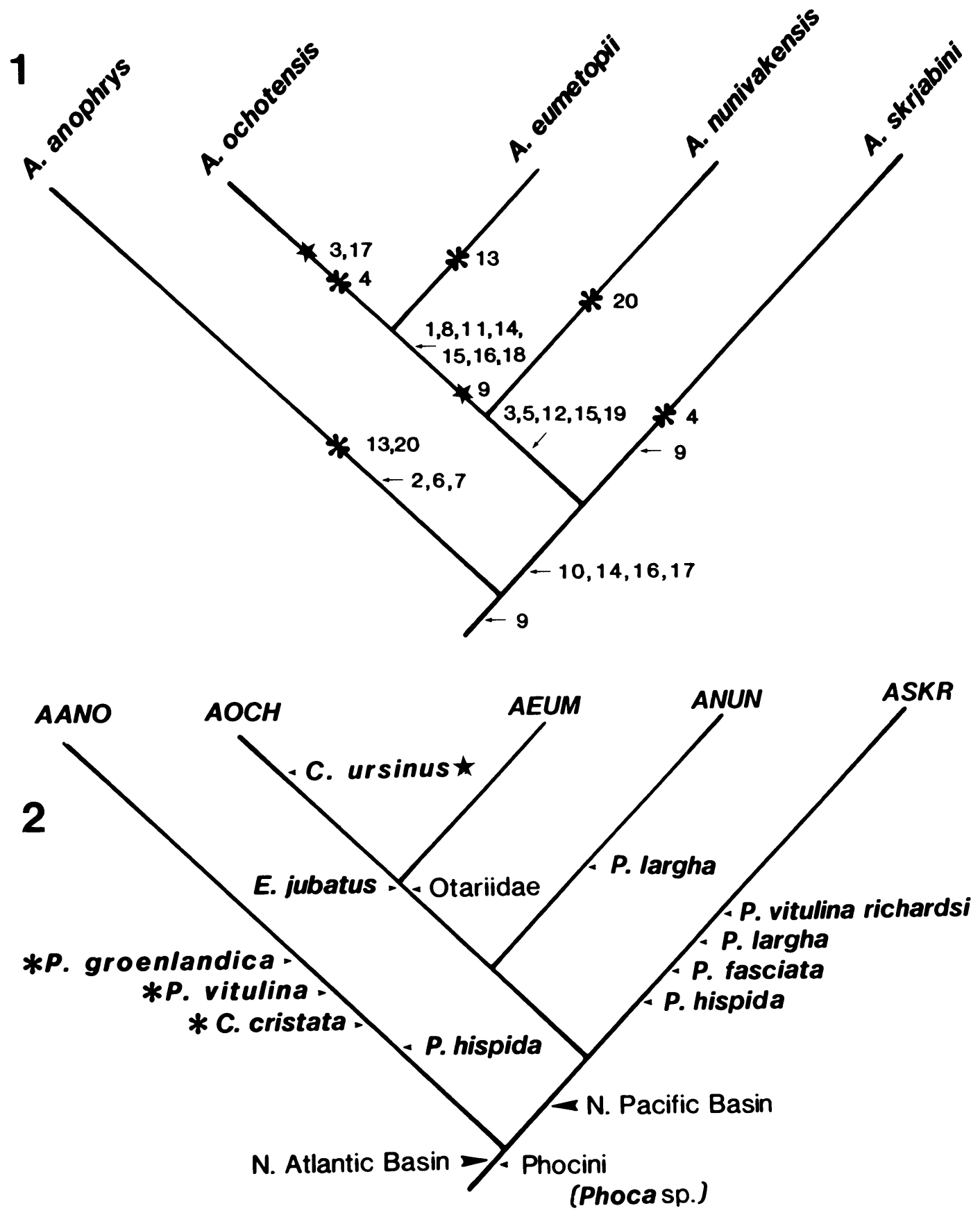

Figures 1, 2. Cladograms showing the phylogenetic hypothesis for 5 Anophryocephalus species with the distribution of pinniped hosts and geographic range mapped onto the parasite tree (from Hoberg and Adams [1992] with permission from the Canadian Journal of Zoology). 1. Phylogenetic hypothesis for Anophryocephalus species; consistency index $=80 \%$. Apomorphic characters are designated by arrows; postulated homoplasy is indicated by asterisks (convergence or parallelisms) and stars (reversals). Characters shown on the tree are consistent with those presented by Hoberg and Adams (1992) and are as follows: 1, development of apical region of scolex; 2 and 3, structure of bothridial opercula; 4, structure of auricular appendages; 5 , parenchymal envelope associated with bothridia; 6 , ventral transverse osmoregulatory system; 7 , dorsal osmoregulatory system; 8 , ventral osmoregulatory system; 9 , length of neck; 10 , position of genital pore; 11 , form of genital pore; 12, shape of cirrus sac; 13, wall of cirrus sac; 14 and 15, form of male papilla in genital atrium; 16 , form of muscular pad 
Brooks and Bandoni, 1988; Hoberg and Adams, 1992).

Development of concepts of host-parasite associations and historical biogeography is dependent upon estimates of parasite phylogeny. Phylogenetic analysis of Anophryocephalus species resulted in a single cladogram (Fig. 1) (Hoberg and Adams, 1992) providing the basis for elucidation of host and biogeographic relationships (Fig. 2).

Appreciation of the temporal aspects and historical biogeography of the assemblage may be gained by considering the history for extant members of the host group (Fig. 3). Within the monophyletic Pinnipedia (Wyss, 1988a, 1988b; Berta et al., 1989) otariids are considered basal, with the odobenids representing the putative sister group for the phocids. Within the Phocidae, the monachines have a basal relationship with respect to the phocines (primary hosts for Anophryocephalus) (de Muizon, 1982; Wyss, 1988a).

The history of otariids and phocids was reviewed recently by Hoberg and Adams (1992). The phocids originated in the North Atlantic Ocean (15 mya) but have a relatively recent history in the North Pacific basin (extending possibly only to 2.5-3.0 mya) when seals of the subgenus Phoca (Pusa) entered through the Bering Strait (open for the first time at 3.0-3.5 mya); radiation followed during the Pleistocene epoch in the North Pacific Ocean. The otariids had a long history in the North Pacific basin (11-12 mya), with fur seals (Arctocephalinae) and sea lions (Otariinae) becoming distributed in the southern hemisphere starting about 5 mya and 3 mya, respectively (Repenning et al., 1979). Precursors of Steller's sea lions are recognized at 2 mya in the Western Pacific basin (Kim et al., 1975).

It is apparent from an examination of pinniped and cestode phylogenies that host and parasite relationships are incongruent, thus supporting a hypothesis for colonization (Fig. 4). Hosts largely are represented by the tribe Phocini (genus Pho$\mathrm{ca}$ ) that radiated extensively in the North Pacific basin during the late Pliocene and Pleistocene epochs. Late colonization of sea lions occurred following divergence of Arctocephalinae and Otariinae (see Berta and Deméré, 1986) and the origin of Eumetopias jubatus (Schreber). Absence of Anophryocephalus from all monachines of the southern hemisphere and most Phocinae of the North Atlantic Ocean (Cystophora cristata (Erxleben), Phoca vitulina Linnaeus, and Phoca (Pagophilus) groenlandica Erxleben are facultative ecological hosts) indicates that Phoca was colonized after 3 mya in the North Atlantic basin. Additionally, absence of these cestodes in all other otariids (except Callorhinus ursinus (Linnaeus), also recognized as a facultative host) is compatible with colonization of sea lions after 2.0 mya in the North Pacific basin. Evolution of Anophryocephalus was thus confined to the Holarctic Region during the late Pliocene epoch and Quaternary period (see Hoberg and Adams, 1992).

The original hosts for Anophryocephalus are phocines (Phoca (Pusa)) from high latitudes in the North Atlantic basin (Fig. 2). Dispersal into the Bering Sea and North Pacific basin via the Arctic basin was followed by vicariance, isolation, and speciation of hosts and parasites. With respect to the host range for Anophryocephalus in the Atlantic basin, ringed seals, Phoca (Pusa) hispida Schreber, are apparently the only typical hosts. The sporadic occurrence of $A$. anophrys in hooded, harp, and harbor seals suggests these are facultative ecological hosts that have not been implicated in the diversification of Anophryocephalus species (Hoberg et al., 1991; Hoberg and Adams, 1992). This implies a secondary (contemporary) host shift following divergence of early phocine stock as no other North Atlantic

in genital atrium; 17, number of testes; 18, position of testes; 19, form of male canal in genital atrium; 20 , vaginal armature. 2. Cladogram for Anophryocephalus species with geographic distributions and host associations mapped onto the parasite tree (from Hoberg and Adams [1992]). Relationships depicted recognize initial colonization of Phocini (Phoca sp.) in the North Atlantic basin. The basal species, Anophryocephalus anophrys (AANO) developed in Phoca (Pusa) sp., whereas Phoca groenlandica, Phoca vitulina, and Cystophora cristata were colonized subsequently and are recognized as facultative ecological hosts (asterisks) (see Hoberg et al., 1991; Hoberg and Adams, 1992). Entry to the North Pacific basin was followed by radiation of Anophryocephalus skrjabini (ASKR) and Anophryocephalus nunivakensis (ANUN) among species of Phoca. Otariids (only Eumetopias jubatus) were colonized by the common ancestor of Anophryocephalus eumetopii (AEUM) and Anophryocephalus ochotensis (AOCH). The occurrence of the latter species in Callorhinus ursinus (a facultative ecological host, indicated by a star) is consistent with a contemporary host shift. 
3
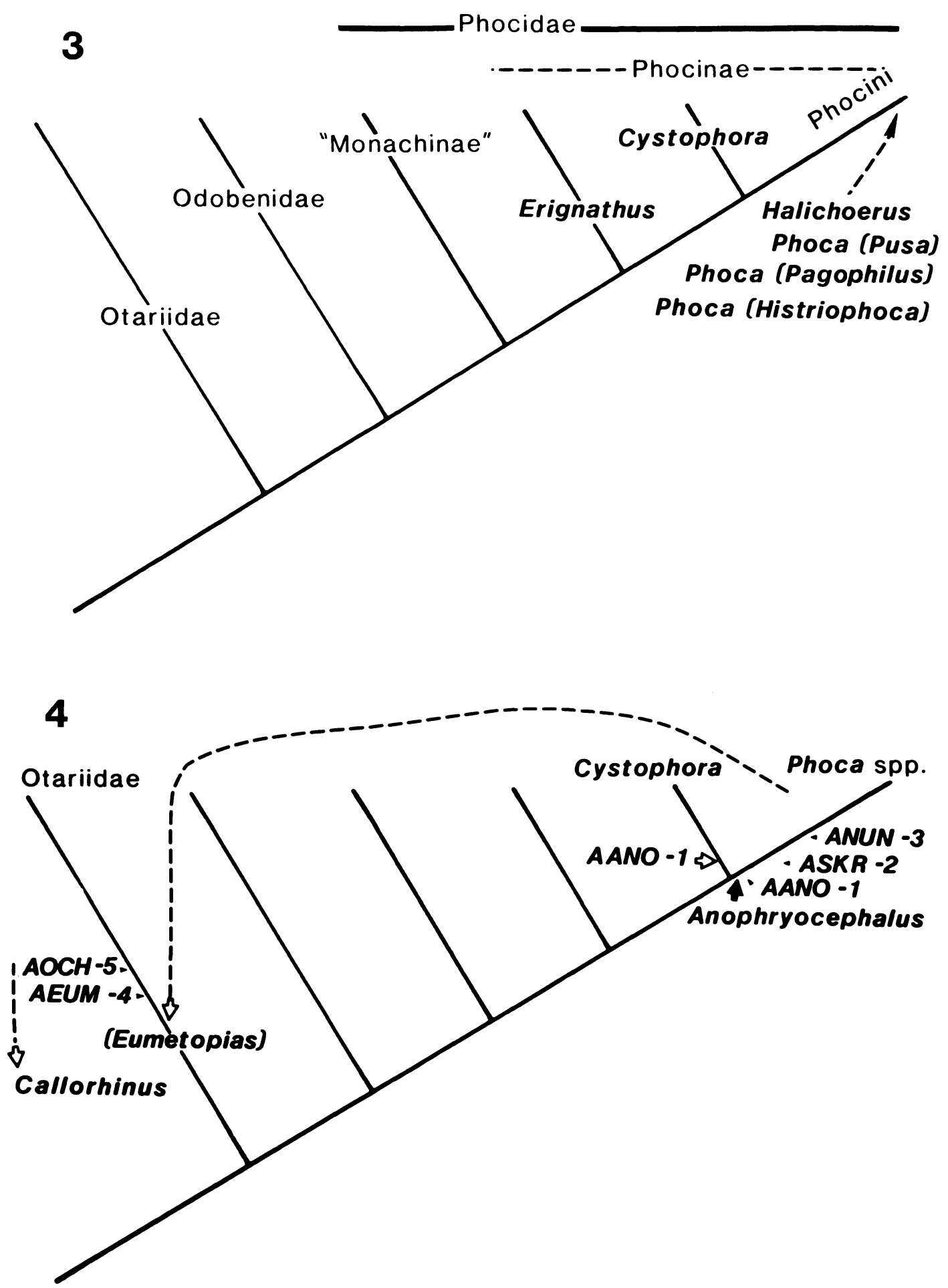

Figures 3, 4. Cladograms showing the phylogenetic hypothesis for the pinnipeds (based on Wyss, 1987, 1988a, 1989; Berta et al., 1989; and from Hoberg and Adams [1992] with permission of the Canadian Journal of Zoology) and the distribution and sequence of colonization of Anophryocephalus species mapped onto the host tree. 3. Phylogenetic hypothesis for extant pinnipeds, showing otariids as basal and odobenids as the putative 
phocines (except $P$. hispida) are recognized as hosts.

Once established in the North Pacific basin, speciation proceeded through the Pleistocene epoch and involved both coevolution and colonization. Coadaptation in P. hispida and Phoca largha Pallas and colonization in Phoca vitulina richardsi (Gray) and Phoca fasciata Zimmermann explains the occurrence of $A$. skrjabini (see Hoberg and Adams, 1992). Parasite speciation without concomitant host speciation accounts for A. nunivakensis as a potential peripheral isolate in P. largha in the eastern Bering Sea. Diversification of $A$. ochotensis and A. eumetopii followed colonization of Steller's sea lions and the limited occurrence of the former species in $C$. ursinus is consistent with a contemporary host shift as no other species of Otariinae or Arctocephalinae is known to be a host (Hoberg and Adams, 1992). Speciation resulted from vicariance and isolation in glacial refugial situations for hosts and parasites (e.g., Sea of Okhotsk, Aleutian Islands) (Hoberg and Adams, 1992) (Fig. 4).

\section{Alcataenia spp. among Alcidae}

Species of Alcataenia are characteristic dilepidids that parasitize seabirds of the families $\mathrm{Al}$ cidae and to a lesser extent Laridae (Hoberg, 1986, 1991, and references therein). Eight species are distributed among the 23 species of alcids extant in the Holocene epoch and all exhibit exceptional host specificity (Table III). Similar to the relationships outlined for Anophryocephalus, the cestode fauna of alcids is depauperate with only $39 \%$ of species in the family being recognized as hosts. Among species occurring in alcids, 1 is endemic to the Atlantic basin (A. atlantiensis), 3 are distributed across the Holarctic Region ( $\mathrm{Al}$ cataenia armillaris (Rudolphi, 1810), Alcataenia meinertzhageni (Baer, 1956), and Alcataenia campylacantha (Krabbe, 1869)), and 4 are endemic to the North Pacific basin (Alcataenia fraterculae Hoberg, 1984, Alcataenia cerorhincae Hoberg, 1984, Alcataenia pygmaeus Hoberg, 1984, and Alcataenia longicervica Hoberg, 1984).

A new phylogenetic analysis is presented for the 8 species of Alcataenia from alcids (modified from Hoberg, 1986). Phylogenetic analysis of $\mathrm{Al}$ cataenia postulated relationships largely identical to previous evaluations (Hoberg, 1986), but now it includes the recently described $A$. atlantiensis. Six trees were produced (consistency in$\operatorname{dex}[\mathrm{CI}]=70.8 \%)$ (as opposed to a single tree with $\mathrm{CI}=77 \%$ in the original analysis [see Hoberg, 1986]) varying in the relative placement of $A$. cerorhincae and $A$. atlantiensis and $A$. longicervica and $A$. armillaris. With respect to the latter pair of species, the preferred topology (see Hoberg, 1986) allowed elimination of the 1 set of relationships for $A$. armillaris and $A$. longicervica. Consequently a consensus tree (strict) was developed for the 3 trees in which the position of $A$. cerorhincae and $A$. atlantiensis was variable (Fig. 5). This tree provides the basis for an evaluation of host and biogeographic associations (Fig. 6).

The development of the Alcataenia-Alcidae assemblage can be examined with respect to phylogeny of the host group (Figs. 7, 8). The hypothesis presented by Strauch (1985) for extant genera of Alcidae forms the basis for the current comparison (although Chandler [1990a] postulated radically different relationships for the al-

$\longleftarrow$

sister group of phocids. "Monachinae" is considered paraphyletic, but monphyly is recognized for Phocinae. Within Phocinae, Cystophora is postulated to be the sister group for the monophyletic tribe Phocini, which includes Halichoerus and the subgenera of Phoca (indicated by an arrow pointing to the terminal branch with Phocini). 4. Cladogram for the pinnipeds indicating pattern of sequential associations for Anophryocephalus species. Numbers indicate postulated sequence of speciation (from Hoberg and Adams, 1992). Original colonization of Phoca is indicated by a solid arrow. Anophryocephalus anophrys (AANO-1), Anophryocephalus skrjabini (ASKR -2), and Anophryocephalus nunivakensis (ANUN-3) are limited to Phocini; Cystophora was secondarily colonized by AANO (open arrow). Eumetopias was the only otariid to be colonized (dashed line, open arrow); specific differentiation resulted in Anophryocephalus eumetopii (AEUM-4) and Anophryocephalus ochotensis (AOCH-5). A later contemporary association is consistent with the distribution of $A$. ochotensis in Callorhinus ursinus (dashed line, open arrow). A minimum of 4 events of colonization within Phocini + Cystophora (including 3 independent contemporary host shifts of AANO to facultative hosts in the North Atlantic basin: Cystophora, Phoca (Pagophilus) groenlandica, and Phoca vitulina) and more recent independent colonization of the otariids (including a contemporary shift of AOCH to northern fur seals) in the North Pacific basin are postulated (see Hoberg and Adams [1992] for an alternative hypothesis for historical relationships, based on the phylogeny for the Phocidae developed by de Muizon [1982]). 
TABLE III. Host and geographic distribution for species of Alcataenia among Alcidae.

\begin{tabular}{|c|c|c|}
\hline Species & Host & Geographic range* \\
\hline $\begin{array}{l}\text { Alcataenia fraterculae } \\
\text { Hoberg, } 1984\end{array}$ & $\begin{array}{l}\text { Horned puffin } \\
\text { Fratercula corniculata }\end{array}$ & $\mathbf{P}$ \\
\hline $\begin{array}{l}\text { Alcataenia cerorhincae } \\
\text { Hoberg, } 1984\end{array}$ & $\begin{array}{l}\text { Rhinoceros auklet } \\
\text { Cerorhinca monocerata }\end{array}$ & $\mathbf{P}$ \\
\hline $\begin{array}{l}\text { Alcataenia pygmaeus } \\
\text { Hoberg, } 1984\end{array}$ & $\begin{array}{l}\text { Whiskered auklet } \\
\text { Aethia pygmaea }\end{array}$ & $\mathbf{P}$ \\
\hline $\begin{array}{l}\text { Alcataenia atlantiensis } \\
\text { Hoberg, } 1991\end{array}$ & $\begin{array}{l}\text { Razorbill } \\
\quad \text { Alca torda }\end{array}$ & At \\
\hline \multirow[t]{2}{*}{$\begin{array}{l}\text { Alcataenia armillaris } \\
\text { (Rudolphi, 1810) }\end{array}$} & $\begin{array}{l}\text { Common murre } \\
\text { Uria aalge }\end{array}$ & $\mathrm{H}$ \\
\hline & $\begin{array}{l}\text { Thickbilled murre } \\
\text { Uria lomvia }\end{array}$ & $\mathrm{H}$ \\
\hline $\begin{array}{l}\text { Alcataenia longicervica } \\
\text { Hoberg, } 1984\end{array}$ & Uria spp. & $\mathbf{P}$ \\
\hline $\begin{array}{l}\text { Alcataenia meinertzhageni } \\
\text { (Baer, 1956) }\end{array}$ & Uria spp. & $\mathbf{H}$ \\
\hline \multirow[t]{3}{*}{$\begin{array}{l}\text { Alcataenia campylacantha } \\
\quad(\text { Krabbe, 1869) }\end{array}$} & $\begin{array}{l}\text { Black guillemot } \\
\text { Cepphus grylle }\end{array}$ & $\mathrm{H} \dagger$ \\
\hline & $\begin{array}{l}\text { Pigeon guillemot } \\
\text { Cepphus colomba }\end{array}$ & $\mathrm{P} \dagger$ \\
\hline & $\begin{array}{l}\text { Spectacled guillemot } \\
\text { Cepphus carbo }\end{array}$ & $\mathrm{O} \dagger$ \\
\hline
\end{tabular}

* P, North Pacific basin; At, eastern Atlantic basin; H, Holarctic Region; O, Okhotsk Sea.

$\dagger$ Alcataenia campylacantha has an overall holarctic range in Cepphus spp.

cids). Considering the sequence of speciation and the occurrence of Alcataenia mapped onto the host cladogram, it is readily apparent that the phylogenetic histories for hosts and parasites are highly incongruent (Fig. 8) (also the case for a preliminary comparison with the hypothesis of Chandler [1990a]). Thus it can be concluded that the current hypotheses for phylogeny of Alcidae, broader associations within the Charadriiformes and the relationships of Alcataenia do not reflect a coevolutionary history for hosts and parasites. Distributions of hosts and parasites are explained best by a sequence of colonization events with minimal coevolution among murres and guillemots (Hoberg, 1986) (Fig. 8).

Although alcids diversified extensively in the Miocene and Pliocene epochs (reviewed by Olson [1985], Hoberg [1984, 1986], Chandler [1991a, 1991b]), initial colonization of the alcids (from larids) is postulated to have occurred during the late Pliocene or early Pleistocene epochs not greater than 3.0 mya. Based on the distribution of cestodes among the alcids and host biogeography, initial hosts are considered to be horned puffins in the North Pacific basin (a recently derived allospecies in the North Pacific Ocean that is parasitized by the host-specific $A$. fraterculae, the basal member of Alcataenia in alcids) (see Hoberg, 1986).

Host and geographic distributions mapped onto the parasite cladogram indicate the assemblage within Alcidae developed via initial colonization in the North Pacific basin from a marine cestode fauna present in Laridae of the Holarctic Region (Hoberg, 1986) (Fig. 6). Basal species of Alcataenia among the larids and alcids are represented by the $A$. larina complex of the Holarctic Region occurring in Rissa tridactyla (Linnaeus) and Larus spp., and include host-specific cestodes of Fratercula, Cerorhinca, and Alca (Fig. 6). In this regard, Chandler (1990b) provided the earliest records of Rissa from the west coast of North America in the Pliocene epoch. This is compatible with the attainment of a broad distribution in the Holarctic Region for Alcataenia sp. in larids prior to colonization of horned puffins in the North Pacific basin.

Subsequent diversification of Alcataenia was associated with sequential colonization of puffins ( $A$. fraterculae and $A$. cerorhincae), razorbills ( $A$. atlantiensis), auklets (A.pygmaeus), and murres (Fig. 6). Three species occurring in Uria species (A. armillaris, $A$. longicervica, $A$. meinertzhageni) developed via cospeciation and coadaptation with the murres, whereas colonization, speciation, and coadaptation occurred among Cepphus species (A. campylacantha) (Hoberg, 1986). This pattern of sequential colonization and a late Pliocene-Pleistocene association of $\mathrm{Al}$ cataenia and Alcidae are also supported by preliminary comparison with the phylogeny of Alcidae presented by Chandler (1990a). The 


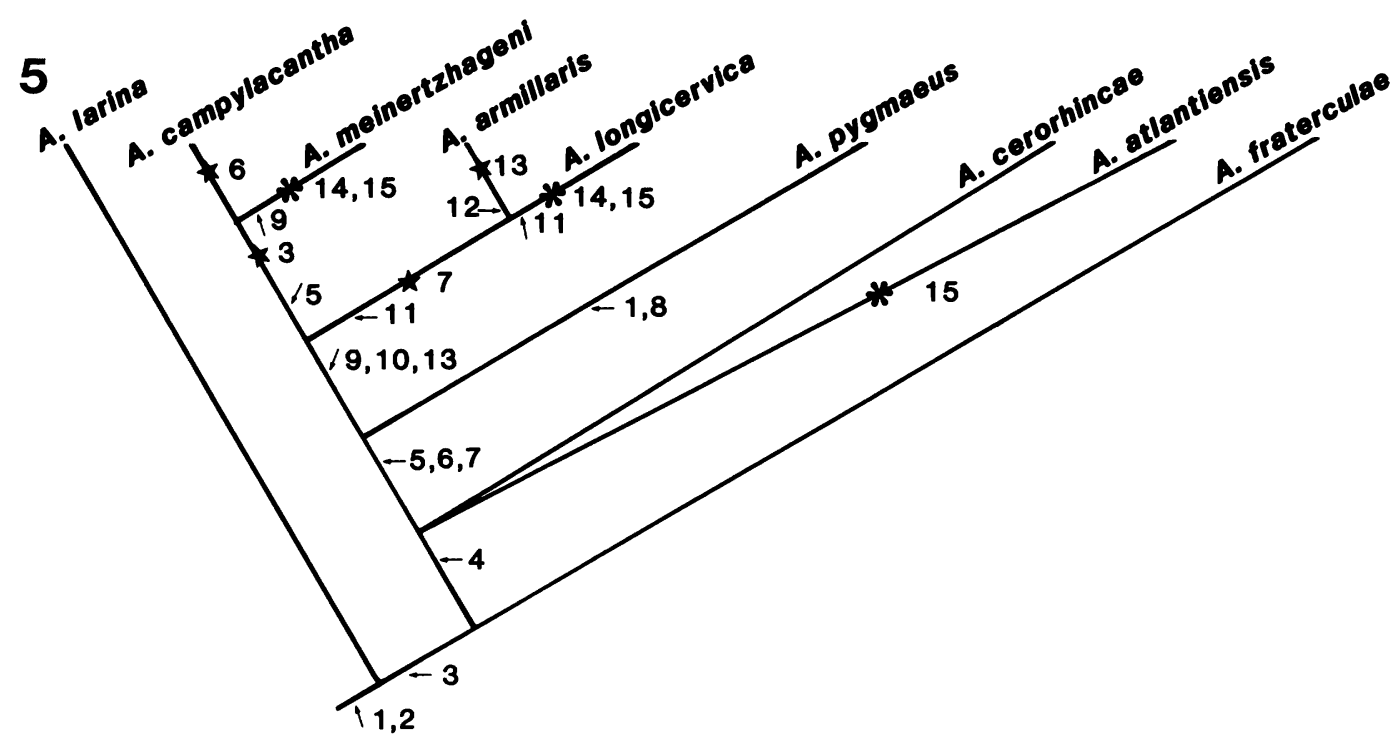

6

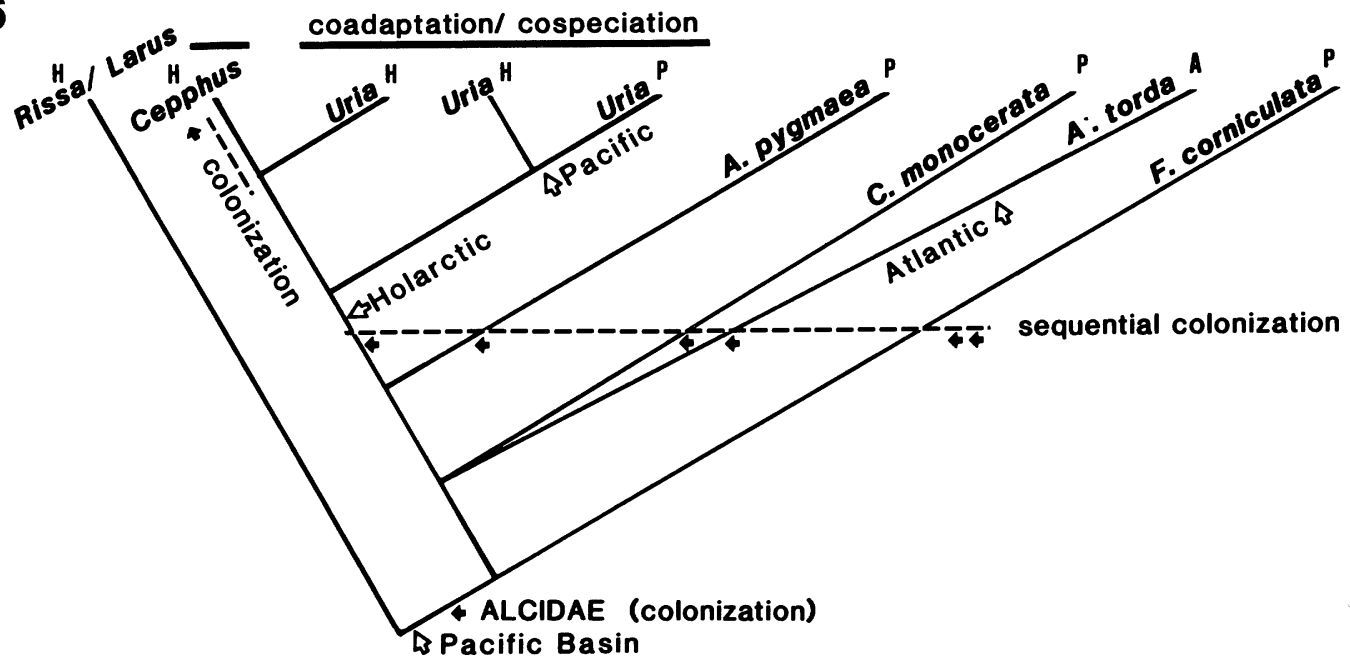

FIGURES 5, 6. Cladograms showing phylogenetic hypothesis for 8 Alcataenia species from alcids (see Hoberg, 1986) with host associations (sequence of colonization and speciation) and geographic distributions mapped onto the parasite tree. 5. Phylogenetic tree for species of Alcataenia rooted with Alcataenia larina. Apomorphic characters are designated by arrows, whereas postulated homoplasy is indicated by asterisks (convergence or parallelism) and stars (reversal). Definition of characters is presented in Table I. The cladogram shown here is a strict consensus tree based on 3 equal-length hypotheses that varied only in the relative placement of Alcataenia cerorhincae and Alcataenia atlantiensis. The consistency index is $70.8 \%$ for this hypothesis. 6. Cladogram for Alcataenia species with geographic distributions and host associations mapped onto the parasite tree. Relationships recognize initial colonization of Alcidae (from Laridae, Rissa and Larus) in the Pacific basin (open arrow base of tree). Radiation and sequential colonization (dashed lines) in the North Pacific basin (except $A$. atlantiensis and Alca torda, the only species endemic to the North Atlantic basin), is associated with cestodes in Fratercula corniculata, Cerorhinca moncerata, Aethia pygmaea, and species of Uria (U. aalge and U. lomvia). Following colonization, a period of coadaptation and cospeciation (solid bar) among species of Uria, and colonization and coadaptation among species of Cepphus (C. columba, C. grylle, and C. carbo) are recognized. Colonization is postulated as being associated with a minimum of $75 \%$ of speciation events for Alcataenia species within Alcidae (see also Brooks and McLennan, 1991). Distributions of Alcataenia armillaris and Alcataenia meinertzhageni in Uria and Alcataenia campylacantha in Cepphus secondarily extended through the Holarctic Region from the Pacific basin, whereas Alcataenia longicervica in Uria is endemic to the North Pacific basin and Bering Sea (indicated by open arrows). Letters labeling terminal branches of the tree indicate geographic distribution as follows: H, Holarctic Region; P, North Pacific basin (including the Bering Sea and Okhotsk Sea); and A, Atlantic basin. 


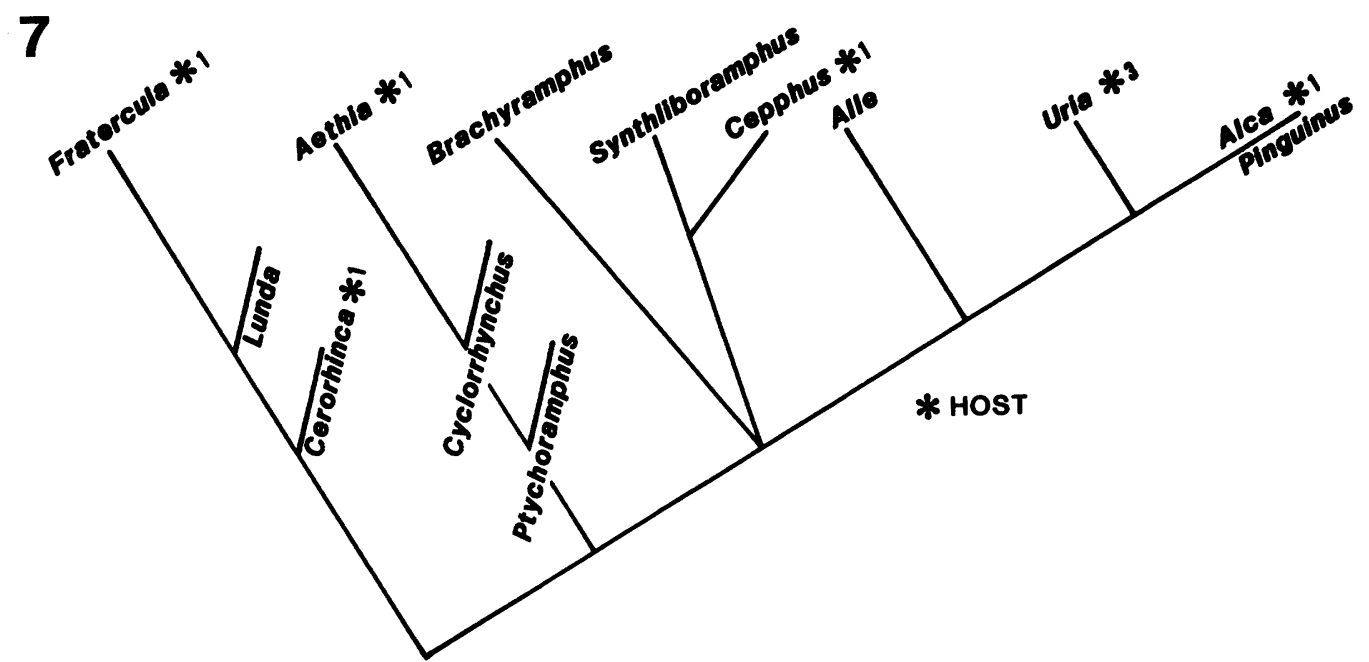

8

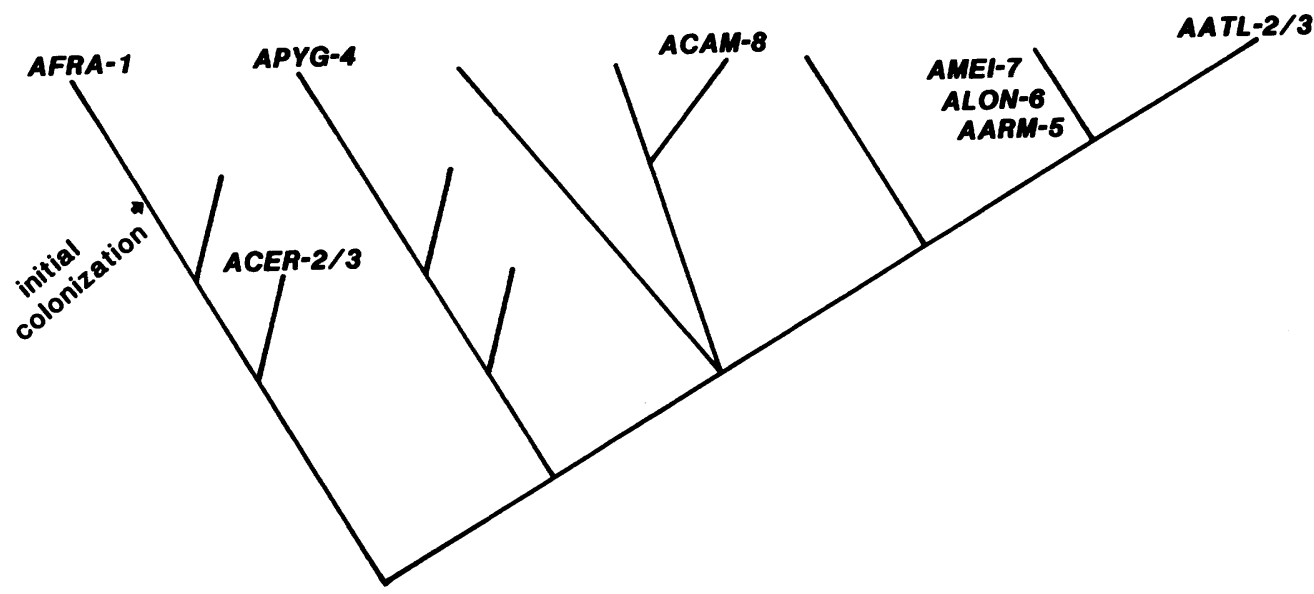

FIGURES 7, 8. Cladograms depicting phylogenetic hypothesis for Alcidae (modified from Strauch, 1985; Hoberg, 1986) and the postulated sequence of host association and parasite speciation mapped onto the host tree. 7. Postulated phylogeny for Alcidae at the generic level. Asterisks indicate hosts for Alcataenia species; numbers indicate species of Alcataenia per host. 8. Cladogram for Alcidae with postulated sequence of speciation of Alcataenia spp. A history of colonization is strongly corroborated by incongruent distributions of Alcataenia species. Numbers indicate sequence of speciation for Alcataenia fraterculae (AFRA-1) in horned puffins, Alcataenia cerorhincae (ACER-2/3) in rhinoceros puffins, Alcataenia atlantiensis (AATL-2/3) in razorbills, Alcataenia pygmaeus (APYG-4) in whiskered auklets, Alcataenia armillaris (AARM-5), Alcataenia longicervica (ALON-6), and Alcataenia meinertzhageni (AMEI-7) in murres, and Alcataenia campylacantha (ACAM8 ) in guillemots. Arrow indicates initial colonization.

generality of the conclusions, irrespective of which host phylogeny is employed (with rejection of strictly vicariant speciation and coevolution and support for colonization and degrees of vicariance and dispersal), is indicative of a robust hypothesis for the development of this host-parasite assemblage. The North Pacific basin was the most important center for radiation of Alcataenia, with diversification of 4 species endemic to the North Pacific Ocean and Bering Sea and the origin of 3 species that later attained extensive ranges in the Holarctic Region in murres and guillemots (Hoberg, 1986) (Fig. 6; Table III).

Diversification of Alcataenia was tied closely to climatic factors during the Pleistocene epoch (Hoberg, 1986). During glacial maxima (periods of maximum eustatic reduction in sea level) areas of the North Pacific basin, Sea of Okhotsk, Aleutian Islands, Queen Charlotte Islands, and the Arctic basin constituted refugial zones. Small effective populations of hosts and parasites were intensely isolated, thus speciation may have been 
promoted. Conversely, during interstadials, ranges of hosts and parasites would expand and the potential for host-switching would be maximized. A general pattern can be postulated for colonization, vicariance, and parasite speciation, often without concomitant host speciation. Allopatric speciation of Alcataenia was determined historically by fluctuating geographic distributions of the host group (Hoberg, 1986).

\section{Historical biogeography of Anophryocephalus and Alcataenia}

Studies of Anophryocephalus and Alcataenia allow recognition of general principles involved in the evolution and distributional history of these disparate faunal assemblages. The cestode faunas of Alcidae (dilepidids) and pinnipeds (specifically tetrabothriids) are depauperate (Tables II, III; Hoberg, 1986; Hoberg and Adams, 1992). Alcids and pinnipeds lack a relictual element of terrestrially derived cestodes. Incongruent phylogenetic histories for respective hosts and parasites refute recognition of these faunas as coevolved numerical relicts (Brooks and Bandoni, 1988; Brooks and McLennan, 1991). Development of Alcataenia (terrestrial origin, see Hoberg [1986]) among a limited number of alcid genera and Anophryocephalus (marine origin, see Hoberg [1987], Hoberg and Adams [1992]) among a restricted group of phocids and otariids is compatible with recent colonization and subsequent radiation. Both faunas are limited to the high boreal latitudes of the Holarctic Region and are strongly influenced by trophic ecology (food habits and foraging behavior) of hosts and distribution of prey organisms (Hoberg, 1984, 1986; Hoberg and Adams, 1992).

Species of Alcataenia and Anophryocephalus are considered to utilize an array of pelagic zooplankton as intermediate hosts (Hoberg, 1986; Hoberg and Adams, 1992). Euphausiid crustaceans (species of Thysanoessa Brandt and Euphausia pacifica Hansen) of the subarctic and transition zones of the Bering Sea and North Pacific Ocean (Ponomareva, 1963; Reid et al., 1978) have been implicated in the life cycles of both genera and are seasonally significant prey for alcids (Ainley and Sanger, 1979; Hunt et al., 1988 ) and some phocids in the region (reviewed by Hoberg and Adams [1992]). Thus it is of interest that the distributional patterns of some species of zooplankton (and fishes) appear to indicate connections between the Pacific and Atlantic basins through the Arctic Ocean (Ekman,
1953; Ponomareva, 1963; Reid et al., 1978). Additionally, Frost (1974) postulated that the episodic emergence of Beringia during the Pleistocene epoch was responsible for disruption of the circumpolar range and isolation of calanoid copepods considered to be the common ancestor for the Calanus finmarchicus (Gunnerus) group. A minimum of 2 cycles of isolation and dispersal were postulated to explain speciation of Calanus marshallae Frost in the Bering Sea and North Pacific basin and Calanus glacialis Jaschnov in the Arctic Ocean. Similarly, Ponomareva (1963) suggested that speciation and the geographic distributions of some species of Thysanoessa in the Holarctic Region may have been determined during the Pleistocene epoch.

The biogeographic history of zooplanktonic intermediate hosts continues to be poorly known, but species distributions and the postulated timing of speciation among some calanoid copepods and euphausiids appear to parallel generally those elucidated for alcids, pinnipeds, and their respective cestode faunas. However, the putative patterns of host-parasite evolution and biogeography for species of Alcataenia and Anophryocephalus also could have developed in the absence of substantial isolation and diversification among zooplanktonic intermediate hosts. There is no general parasitological rule that would predict constant rates of evolution and speciation, following the origin of a life cycle, among such disparate taxa as those represented by the array of definitive (alcids and pinnipeds) and intermediate (euphausiids and other zooplankton) hosts and parasites constituting these assemblages.

In such marine systems the isolation of parasite populations appears controlled predominantly by the distributions of otherwise highly vagile sea birds and marine mammals that disseminate oncospheres infective for the intermediate host (also see comments by Hoberg [1986] concerning philopatry among alcids). In contrast, pelagic macrozooplankton such as euphausiids have severely limited abilities for rapid dispersal and have patchy distributions confined to specific, relatively large, oceanic circulation systems (McGowan, 1974, 1977; Reid et al., 1978). As a consequence, such crustaceans will be of limited significance in maintaining cohesion of specific parasite populations through gene flow. This is particularly the case as foraging by alcids and pinnipeds often is localized near colony sites and usually is correlated with predict- 


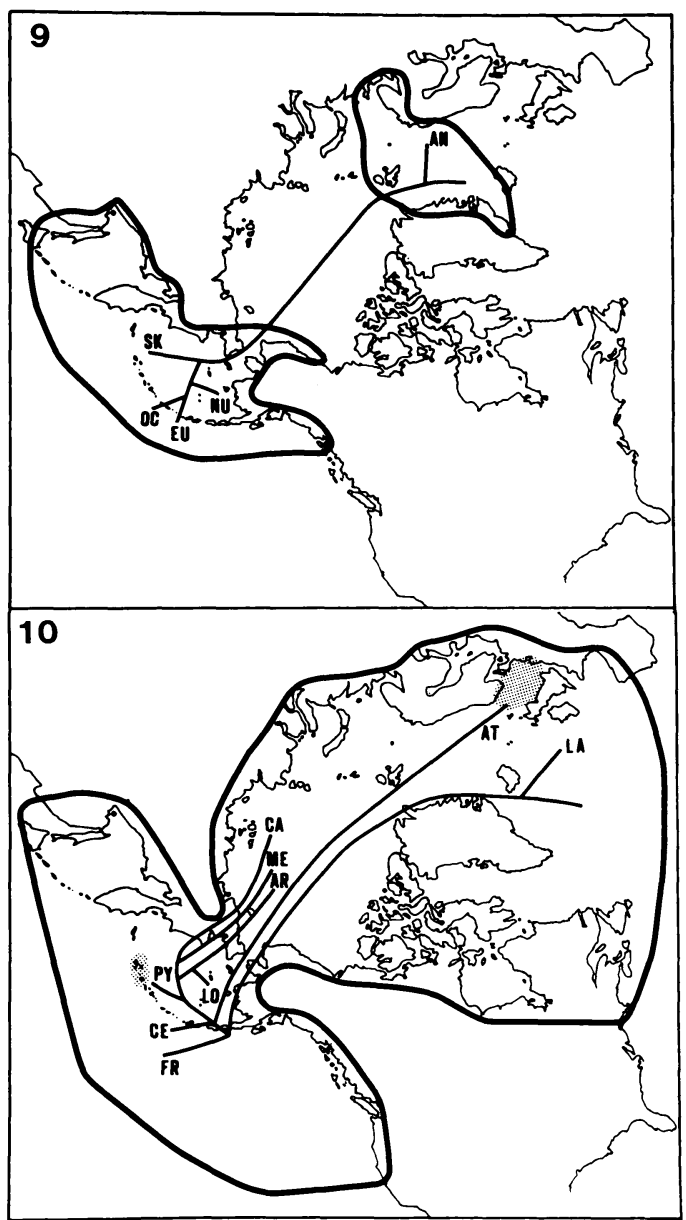

Figures 9, 10. Area cladograms for species of $\mathrm{An}$ ophryocephalus and Alcataenia produced by superimposing the parasite cladogram on the geographic distribution of the respective cestode genera. 9. Relationships for Anophryocephalus species (AN, $A$. anophrys; SK, A. skrjabini; NU, A. nunivakensis; EU, $A$. eumetopii; and OC, $A$. ochotensis) (modified from Hoberg and Adams [1992]). 10. Relationships for $\mathrm{Al}$ cataenia spp. in larids and alcids (LA, A. larina; FR, A. fraterculae; CE, $A$. cerorhincae; AT, A. atlantiensis; PY, A. pygmaeus; AR, A. armillaris; LO, A. longicervica; $\mathrm{ME}, A$. meinertzhageni; and CA, $A$. campylacantha). The shaded areas adjacent to branches for $A$. pygmaeus and $A$. atlantiensis indicate the apparently restricted ranges of these cestodes in the western Aleutian Islands and North Sea, respectively. Consult text for explanation of relationships depicted in figures.

able zones of frontal circulation and tidal eddy systems associated with islands (Hunt and Schneider, 1987; Hunt et al., 1988). In this respect insular marine systems and adjacent pelagic waters appear to represent foci for parasite transmission (Hoberg, 1984).
Accordingly, isolation and speciation among alcids, pinnipeds, and their respective cestode faunas could have proceeded independently from that of populations of requisite intermediate hosts. Biotic components of these marine parasite assemblages may not have been influenced to the same degree by episodic fluctuations in climate and sea level that characterized the Pleistocene epoch. However, it is the repeated patterns for speciation of definitive hosts and parasites, recoverable through phylogenetic analysis (Brooks and McLennan, 1991), that are apparent in the present study irrespective of the biogeographic and evolutionary histories of the putative intermediate hosts required for successful transmission.

Aside from the influence of trophic interactions on hosts and parasites, host specificity appears to have been a constraint on diversification of these cestodes (continued colonization and radiation) in alcids and pinnipeds. The development of this latter phenomenon was rapid and consequently not a direct indicator of the duration of historical associations among hosts and parasites (see Brooks, 1979, 1985; Hoberg, 1986; Brooks and McLennan, 1991; Hoberg and Adams, 1992). Additionally, morphological evolution was not uniformly linked to host-switching and there was minimal radiation (as indicated by generally depauperate faunas) in previously unexploited host groups, suggesting limited importance for ecological determinism in the diversification of species of Anophryocephalus and Alcataenia.

Common area relationships can be outlined for the distribution of Anophryocephalus and $\mathrm{Al}$ cataenia (Figs. 9, 10). Area cladograms produced by superimposing the parasite phylogeny on the area of distribution in the Holarctic Region largely are congruent. The history of Anophryocephalus involved 2 primary areas: the North Atlantic basin corresponding with the origin and current range of $A$. anophrys and the North Pacific Ocean, corresponding with the region of greatest diversification. This general pattern resulted from early vicariance and radiation in the North Pacific Ocean and Bering Sea without subsequent dispersal to the Atlantic Ocean via the Arctic basin (Fig. 9).

The area relationships for Alcataenia are more complex because of the number of holarctic species. However, it is possible to recognize an origin among larids in the North Atlantic basin (attainment of a holarctic range for $A$. larina). 
Subsequent colonization of alcids (horned puffins) and radiation in the North Pacific basin was followed by the secondary development of ranges through the Arctic basin for A. armillaris, A. meinertzhageni, and $A$. campylacantha (Fig. 10). There is a high degree of congruence in these biogeographic patterns, and, based on host associations, evidence has been presented that supports hypotheses for incongruent phylogenetic histories but a general synchrony in speciation events during radiation of both assemblages of hosts and parasites since the Pliocene Epoch. An integrated summary of the evolutionary and biogeographic histories of Anophryocephalus and Alcataenia is consistent with concepts of sequential colonization and extremes in climate as determinants of diversification and distribution of these faunas (Fig. 11).

The late Pliocene and Pleistocene epochs was a period of dynamic climatic extremes that directly defined paleogeography in coastal habitats (Davies, 1958; Hopkins, 1971; Wise and Schopf, 1981) and influenced patterns of speciation and extinction (Hoberg, 1986; Hoberg and Adams, 1992; also see Vrba, 1985). The cyclic patterns of stadials and interstadials were determinants of extensive environmental disruption and vicariance due to eustatic variation in sea level. It was within this physical and biological arena that diversification of hosts and parasites occurred within isolated refugia in the Arctic, Subarctic, and Boreal zones. Speciation during stadials was followed by range expansion and host switching, and, since the Pleistocene epoch, faunal assemblages have been influenced further by contemporary seasonal migratory patterns and ecological association of hosts.

Historical determinants for Anophryocephalus and Alcataenia can be defined further. It is apparent that although successful colonization is not predictable, it is still dependent upon longterm ecological (usually trophic) interactions (Hoberg, 1986, 1987; Brooks and Bandoni, 1988; Brooks and McLennan, 1991; Hoberg and Adams, 1992). Although the host-parasite assemblages associated with Alcataenia and Anophryocephalus were structured by colonization, climatic influences, particularly glacial extremes, appear as significant determinants of diversification within refugia. However, diversification of these assemblages was constrained by host specificity and host trophic ecology (see Hoberg, 1986; Hoberg and Adams, 1992). Assemblages may have been limited further to the subarctic during

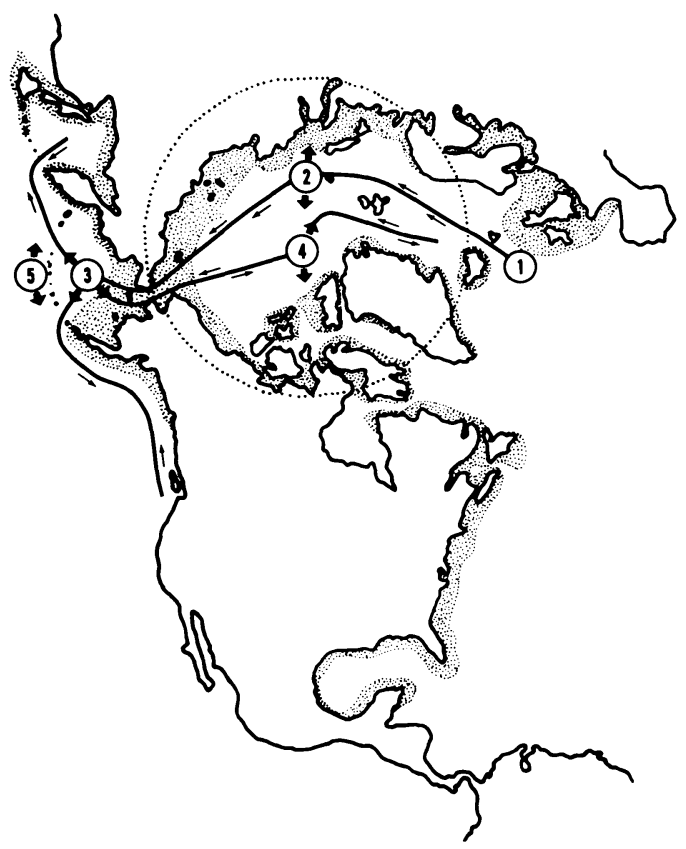

FIGURE 11. Summary of historical biogeography for Anophryocephalus species among the phocids and otariids and Alcataenia species among Alcidae. Map shows extent of exposed continental shelf(shaded region) during eustatic reduction in sea level to $-100 \mathrm{~m}$ during glacial maxima (modified from Wise and Schopf, 1981). Partitioning of North Pacific basin and Arctic basin into regional (e.g., Arctic basin, Pacific basin, Okhotsk $\mathrm{Sea})$ and insular refugia (e.g., Aleutian Islands and $\mathrm{Ku}$ rile Islands) was influenced by fluctuations in sea level. The postulated origin of Anophryocephalus in Phoca sp. and Alcataenia in larids was in the North Atlantic (ca. 3.0-3.5 million years ago [mya]) (indicated by 1). Subsequently, range expansion occurred through the Arctic basin and resulted in the development of early holarctic distributions for hosts and parasites (ca. 2.53.0 mya) (indicated by 2). Initial entry to the North Pacific basin through Bering Strait (ca. 2.5-3.0 mya) occurred soon after the submergence of Beringia (indicated by 3). Alcataenia species diversified, following colonization of puffins, through sequential colonization and radiation in auklets, murres, and guillemots (starting $<2.5 \mathrm{mya}$ ), and radiation of Anophryocephalus ensued among Phoca species in the North Pacific basin (starting $<2.5$ mya). Secondary holarctic ranges were attained later by Alcataenia species among murres and guillemots during the Quaternary period (indicated by 4). Colonization of Eumetopias (ca. $<2.0$ mya) was followed by speciation of $A$. ochotensis and A. eumetopii (indicated by 5).

interglacials by a relatively closed oceanographic system in the North Pacific and Bering Sea that strongly limited the distribution of prey organisms that served as intermediate hosts (see Hoberg and Adams [1992] and references therein). Additionally, relatively limited vagility of pin- 
nipeds as compared to seabirds would have regulated movement via the Arctic basin into the Atlantic Ocean for Anophryocephalus.

These concepts form the basis for a marine refugium hypothesis. Speciation of hosts and parasites coincided with partitioning of the North Pacific basin (and high latitudes of the Holarctic Region) into refugial zones during glacial maxima coinciding with periods of maximum eustatic reduction in sea level. Range contraction, vicariance, isolation, and speciation occurred during stadials. Range expansion from refugial centers and colonization occurred during interstadials. These alternating sequences of climatic extremes constituted the driving mechanism of diversification rather than extinction among disparate taxa in marine environments at high boreal latitudes of the Holarctic Region during the late Pliocene and Pleistocene epochs (see also SiegelCausey [1991] with reference to the similar biogeographic history of shags, Stictocarbo species, in the western North Pacific Ocean). Far Eastern marginal seas of the North Pacific and adjacent areas are postulated to have served as critical biogeographic refugia during the Quaternary period.

\section{ACKNOWLEDGMENTS}

Recent field collections of alcids and their helminth parasites at Talan Island in the Sea of Okhotsk, U.S.S.R., were conducted in 1988 under the Interacademy Exchange Program of the National Academy of Sciences. Logistical support in the Soviet Union was provided by the Institute of Biological Problems of the North, Far Eastern Scientific Center, Academy of Sciences of the U.S.S.R., Magadan. Additional collections of marine birds were conducted with curators of the Zoology Division of the Burke Museum, University of Washington, during pelagic cruises off the Washington coast supported by Garret Eddy. Some preliminary aspects of analyses of pinniped parasites were supported by a grant in population biology from the Natural Sciences and Engineering Research Council of Canada. Contributions to this study by A. M. Adams, R. L. Rausch, D. R. Brooks, D. Siegel-Causey, and A. $\mathrm{R}$. Wyss are gratefully acknowledged.

\section{LITERATURE CITED}

Ainley, D. G., ANd G. A. Sanger. 1979. Trophic relationships of seabirds in the northeastern $\mathrm{Pa}$ cific Ocean and Bering Sea. In Conservation of marine birds of northern North America, J. C. Bartonek and D. N. Nettleship (eds.). U.S. De- partment of the Interior, Internal Wildlife Research Report No. 11, p. 95-122.

Berta, A., AND T. Deméré. 1986. Callorhinus gilmorei n. sp. (Carnivora: Otariidae) from the San Diego Formation (Blancan) and its implications for otariid phylogeny. Transactions of the San Diego Society of Natural History 21: 111-126.

- C. E. RAY, AND A. R. Wyss. 1989. Skeleton of the oldest known pinniped, Enaliarctos mealsi. Science 244: 60-62.

BRooks, D. R. 1979. Testing the context and extent of host-parasite coevolution. Systematic Zoology 19: 299-307.

- 1985. Historical ecology: A new approach to studying the evolution of ecological associations. Annals of the Missouri Botanical Garden 72: 660 680.

$\longrightarrow$, AND S. M. BANDONI. 1988. Coevolution and relicts. Systematic Zoology 37: 19-33.

ecology and behavior: A research program in comparative biology. University of Chicago Press, Chicago, Illinois, $434 \mathrm{p}$.

Chandler, R. M. 1990a. Phylogenetic analysis of the alcids. Ph.D. Dissertation. University of Kansas, Lawrence, Kansas, 133 p.

- 1990b. Recent advances in the study of fossil birds. II. Fossil birds of the San Diego Formation, late Pliocene, Blancan, San Diego County, California. Ornithological Monographs 44: 75-160.

DAvies, J. J. 1958. Pleistocene geography and the distribution of northern pinnipeds. Ecology 39: 97113.

DE Muizon, C. 1982. Phocid phylogeny and dispersal. Annals of the South African Museum 89: 175213.

Ekman, S. 1953. Zoogeography of the sea. Sidgwick and Jackson Publishers, London, U.K., 417 p.

Frost, B. W. 1974. Calanus marshallae, a new species of calanoid copepod closely allied to the sibling species $C$. finmarchicus and $C$. glacialis. Marine Biology 26: 77-99.

HenNig, W. 1966. Phylogenetic systematics. University of Illinois Press, Urbana, Illinois, 263 p.

Herman, Y., AND D. M. Hopkins. 1980. Arctic oceanic climate in late Cenozoic time. Science 209: 557-562.

HOBERG, E. P. 1984. Systematics, zoogeography and ecology of platyhelminth parasites of the seabird family Alcidae (Charadriiformes: Suborder Alcae). Ph.D. Dissertation. University of Washington, Seattle, $324 \mathrm{p}$.

- 1986. Evolution and historical biogeography of a parasite-host assemblage: Alcataenia spp. (Cyclophyllidea: Dilepididae) in Alcidae (Charadriiformes). Canadian Journal of Zoology 64: 2576 2589.

- 1987. Recognition of larvae of the Tetrabothriidae (Eucestoda): Implications for the origin of tapeworms in marine homeotherms. Canadian Journal of Zoology 65: 997-1000.

- 1989. Phylogenetic relationships among genera of the Tetrabothriidae (Eucestoda). Journal of Parasitology 75: 617-626.

- 1991. Alcataenia atlantiensis n. sp. (Dilepididae) from the razorbill (Alca torda Linnaeus) in 
the eastern North Atlantic basin. Systematic Parasitology 20: 83-88.

, AND A. M. AdAms. 1992. Phylogeny, historical biogeography and ecology of Anophryocephalus spp. (Eucestoda: Tetrabothriidae) among pinnipeds of the holarctic during the late Tertiary and Pleistocene. Canadian Journal of Zoology 70: (in press).

, AND R. L. RausCh. 1991. Revision of the genus Anophryocephalus Baylis, 1922 from pinnipeds in the holarctic, with descriptions of Anophryocephalus nunivakensis sp. n. and $A$. eumetopii sp. n. (Tetrabothriidae) and evaluation of records from the Phocidae. Canadian Journal of Zoology 69: 1653-1668.

HopkINS, D. M. 1971. The paleogeography and climate history of Beringia during late Cenozoic time. Internord 12: 121-150.

Hunt, G. L., N. M. Harrison, W. M. Hamner, AND B. S. OBST. 1988. Observations of a mixedspecies flock of birds foraging on euphausiids near St. Matthew Island, Bering Sea. Auk 105: 345349.

—, AND D. C. SChneider. 1987. Scale development processes in the physical and biological environment of seabirds. In Seabirds feeding ecology and role in marine ecosystems, J. P. Croxall (ed.). Cambridge University Press, New York, p. $7-41$.

IURAKHNO, M. V. 1987. Studies on the population structure of northern fur seals. In Parasitology and pathology of marine organisms, A. V. Gaevskaja (ed.). Atlantic Research Institute of Fisheries and Oceanography, Kaliningrad, U.S.S.R., p. 144-145. [In Russian.]

Kim, K. C., C. A. Repenning, and G. V. Morejohn. 1975. Specific antiquity of the sucking lice and evolution of otariid seals. Rapports et Proces-Verbaux des Reunions, Conseil International pour l'Exploration de la Mer 169: 544-549.

MAtThews, J. V., JR. 1981. Tertiary and Quaternary environments: Historical background for an analysis of the Canadian insect fauna. Memoirs of the Entomological Society of Canada 108: 31-86.

McGowan, J. A. 1974. The nature of oceanic ecosystems. In The biology of the oceanic Pacific, C. B. Miller (ed.). Oregon State University Press, Corvallis, Oregon, p. 8-28.

. 1977. What regulates pelagic community structure in the Pacific? In Oceanic sound scattering prediction, N. R. Andersen and B. J. Zahuranec (eds.). Plenum Press, New York, p. 423443.
Olson, S. L. 1985. The fossil record of birds. In Avian biology, Vol. 8, D. S. Farner, J. R. King, and K. C. Parks (eds.). Academic Press, New York, p. 80-256.

Ponomareva, L. A. 1963. Euphausiids of the north Pacific, their distribution and ecology. Isdatel'stvo Akademii Nauk S.S.S.R., Moscow, U.S.S.R. [English translation, Israel Program for Scientific Translations, Jerusalem, 1966, 154 p.]

Reid, J. L., E. Brinton, A. Flemminger, E. L. VenRICK, AND J. A. MCGowan. 1978. Oceanic circulation and marine life. In Advances in oceanography, H. Charnock and G. Deacon (eds.). Plenum Press, New York, p. 65-130.

Repenning, C. A., C. A. Ray, and D. Grigorescu. 1979. Pinniped biogeography. In Historical biogeography, plate tectonics, and the changing environment, J. Gray and A. J. Boucot (eds.). Oregon State University Press, Corvallis, Oregon, p. 357369.

Siegel-Causey, D. 1991. Systematics and biogeography of North Pacific shags, with a description of a new species. Occasional Papers of the Museum of Natural History, University of Kansas, Lawrence, Kansas 140: 1-17.

Strauch, J. G. 1985. Phylogeny of the Alcidae. Auk 102: 520-539.

Swofford, D. L. 1985. Phylogenetic analysis using parsimony. Version 2.4. Illinois Natural History Survey, Champaign, Illinois, $78 \mathrm{p}$.

VRBA, E. S. 1985. Environment and evolution: Alternative causes of the temporal distribution of evolutionary events. South African Journal of Science 81: 229-236.

Wiley, E. O. 1981. Phylogenetics. The theory and practice of phylogenetic systematics. John Wiley and Sons, Inc., New York, 439 p.

Wise, K. P., AND T. J. M. SCHOPf. 1981. Was marine faunal diversity in the Pleistocene affected by changes in sea level? Paleobiology 7: 394-399.

Wyss, A. R. 1987. The walrus auditory region and the monophyly of pinnipeds. American Museum Novitates 2871: 1-31.

—. 1988a. On "retrogression" in the evolution of the Phocinae and phylogenetic affinities of the monk seals. American Museum Novitates 2924: $1-38$.

- 1988b. Evidence from flipper structure for a single origin of pinnipeds. Nature 334: 427-428.

1989. Flippers and pinniped phylogeny: Has the problem of convergence been overrated? Marine Mammal Science 5: 343-360. 